\title{
Logistic Regression Model for Assessing Factors Affecting Timeliness of Financial Statement
}

Submission

\author{
Eri Ayu Rumiyani ${ }^{1}$ \\ Program Studi Manajemen \\ Sekolah Tinggi Ilmu Manajemen \\ YKPN Yogyakarta, Indonesia \\ Ralina Transistari ${ }^{3}$ \\ Program Studi Manajemen \\ Sekolah Tinggi Ilmu Manajemen \\ YKPN Yogyakarta, Indonesia
}

\author{
Siti Resmi² \\ Program Studi Manajemen \\ Sekolah Tinggi Ilmu Manajemen \\ YKPN Yogyakarta, Indonesia
Muhammad Roni Indarto ${ }^{4}$
Program Studi Manajemen
YKPN Yogyakarta, Indonesia \\ Sekolah Tinggi Ilmu Manajemen
}

\begin{abstract}
Financial information is helpful if it fulfills fundamental characteristics. One of these characteristics is timeliness. This article aims to examine the elements that affect financial statement timeliness. This research is conducted on mining companies listed on the Indonesian stock exchange from 2016 to 2018 . The data analyzed were panel data of 69 observations obtained from 23 companies over three years. The data was processed using Eviews 9 and logit regression analysis techniques. The investigation demonstrates that the current ratio has a considerable favorable influence on the timeliness of financial statements for a variety of mining businesses listed on the IndonesianStock Exchange (IDX) between 2016 and 2018. On the other hand, return on assets, and company size has no significant effect on the timeliness of financial statements. The implication of the results of this study is that better regulations are needed to improve public companies in submitting financial reports on time. Published financial statements are information for making informed decisions by interested users.
\end{abstract}

Surel: ralina_tr@yahoo.com

Keywords: Current Ratio; Return on Asset; Company Size; Financial Statement; Logistic Regression Model.

\section{Model Regresi Logistik untuk Menilai Faktor-Faktor yang Mempengaruhi Ketepatan Waktu Penyampaian Laporan Keuangan}

\begin{abstract}
ABSTRAK
Informasi keuangan berguna jika memenuhi karakteristik fundamental. Salah satu karakteristik tersebut adalah ketepatwaktuan ketepatan waktu. Tujuan dari penelitian ini yaitu untuk mengkaji faktor-faktor yang mempengaruhi ketepatwaktuan laporan keuangan. Penelitian dilakukan pada perusahaan pertambangan yang terdaftar di Bursa Efek Indonesia dari tahun 2016hingga 2018. Data yang dianalisis adalah data panel dari 69 observasi yang diperoleh dari 23 perusahaan selama tiga tahun. Pengolahan data menggunakan Eviews9 dan teknik analisis regresi logit. Hasil analisis menunjukkan bahwa current ratio berpengaruh positif signifikan terhadap ketepatwaktuan laporan keuangan berbagai perusahaan pertambangan yang diteliti. Di sisi lain, return on assets dan ukuran perusahaan tidak berpengaruh signifikan terhadap ketepatan waktu laporan keuangan. Implikasi dari hasil penelitian ini adalah diperlukan regulasi yang lebih baik untuk meningkatkan perusahaan publik dalam menyampaikan laporan keuangan tepat waktu. Laporan keuangan yang dipublikasikan adalah informasi untuk membuatkeputusan yang tepatoleh pengguna yang berkepentingan.
\end{abstract}

Kata Kunci: $\quad$ Current Ratio; Returnon Asset; Ukuran perusahaan; Laporan keuangan; Model Regresi Logistik.

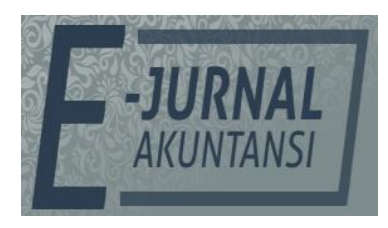

e-ISSN 2302-8556

Vol. 31 No. 12

Denpasar, Desember 2021 Hal. 3000-3010

DOI:

10.24843/EJA.2021.v31.i12.p05

PENGUTIPAN:

Rumiyani, E. A., Resmi, S., Transistari, R. \& Indarto, M. R. (2021). Logistic Regression Model for Assessing Factors Affecting Timeliness of Financial Statement Submission. E-Jurnal Akuntansi, 31(12), 3000-3010

RIWAYAT ARTIKEL:

Artikel Masuk: 26 Mei 2021 Artikel Diterima: 9 Desember 2021

Artikel dapat diakses: https:/ /ojs.unud.ac.id/index.php/Akuntansi/index 


\section{INTRODUCTION}

The publication of financial statements is essential for the company. Financial statements are a source of information about the financial position, financial performance, and changes in financial situation, especially the cash flow of a company. The financial statement information becomes the basis for making decisions for users interested in both internal users and external users. Internal users are management and external users, namely investors, creditors, the government, and the public. Internal and external users need timeliness of financial reporting of public companies is required by Rakhman and Wijayana (2019). Delay in reporting financial statements can reduce the benefits of financial statements for various user groups (Atiase et al., 1989). Stakeholders recognize that when reporting delays occur, the risk of bankruptcy is higher and poor performance occurs. The state institutions that control the accuracy of the submission of financial statements must take stringent steps for companies that delay submitting financial statements for a long time (Lukason \& CamachoMiñano, 2019). In Indonesia, public companies are required to publish financial reports regularly and on time. Many users of financial statements have an interest in quality financial reports. Timeliness is one of the criteria for the quality of financial statements. Users of financial information such as regulators and professional accounting authorities have deep concern about the timeliness of financial statements (Zandi \& Abdullah, 2019). According to Soltani (2002), one of the relevant characteristics in assessing the benefits of financial information is the timeliness of financial statements.

Public companies are required to submit financial reports to the public. The obligation of public companies to submit financial reports is regulated in Capital Market Regulation No.29/PJOK.04/2016. The annual report is submitted to the financial services authority (FSA). The deadline for submission is the end of the fourth month after the end of the financial year. Capital Market Regulation No.29/PJOK.04/2016 states that public companies are required to submit an annual report to the financial services authority (OJK) no later than the end of the fourth month after the end of the financial year. Public companies that do not submit audited financial statements by the deadline are subject to sanctions. The sanction is given by the Indonesia Stock Exchange (IDX). The FSA and IDX monitor and sanction public companies that are late in submitting financial reports. Monitoring and imposition of sanctions are carried out to ensure that public companies have complied with the provisions for listing securities and are open in providing information to the public. OJK currently assesses that there are still many companies that are not disciplined in implementing these regulations. The fact is that there are still companies that are late in submitting their financial reports.

Regulations on the delivery of financial statements are regulated in rules, but in reality, some companies submit financial reports that are not timely. Several studies on the factors that influence the timeliness of financial statement submission have been carried out. Many researchers examine the effect between timeliness of financial statements and accounting information, for example, Bagnoli et al. (2002), Graham et al. (2005), Sengupta (2004), Ha et al. (2018), Raihani et al. (2019). Many factors allow managers to provide annual and timely reports to 
reduce the cost of late reporting, for example, company size, current ratio, financial leverage, and profitability (G Hamidi \& Rasouli, 2016). However, these studies get different results. Hamidi \& Rasouli (2016) found a negative and insignificant relationship between the current ratio and profitability with the delay in financial reporting. Ha, et al. (2018) examined the independent variables, namely the financial statements consolidated in connection with financial statement timely, audit firms, profitability and size of the business. The results found profitability and business size affect the timeliness of financial statements. Research conducted by Suadiye (2019) concluded that the impact of profitability and company size on the timeliness of financial statements is negative and significant.

The current ratio shows its ability to pay off current liabilities using its current assets (Umobong, 2015). The high current ratio implies that the business possesses an extraordinary ability to repay its debts. Companies with a high current ratio will present financial statement to the public more rapidly. According to Kasmir (2019), current ratio is the ratio between total current assets and current liabilities. The higher the current ratio, the higher the company's ability to pay off its debts. Thus the company will quickly submit its financial statements to the public because the company has no problems in its short-term debt. This condition is good news for the company. This theory is proven by Hastutik (2015), who found that liquidity has an effect on the timeliness of submitting financial statements with the direction of the regression coefficient in the study being positive. This means that the higher the level of liquidity significantly affects the lower the level of timeliness of the submission of financial statements. This theory is also supported by Dewi et al. (2021) who found empirical evidence that the current ratio significantly affects the timeliness of submitting financial statements. Hight current ratio is a positive development for the business. Lukason \& Camacho-Miñano (2019) found that companies with lower liquidity values tended to postpone reporting annual financial statements during legal deadlines. In other words, companies with high liquidity will report financial statements on time. According to Hamidi \& Rasouli (2016), as a result, current ratios negatively affect the overall accuracy of financial accounts.

$\mathrm{H}_{1}$ : Current Ratio has a Positive Affect on Timeliness of Financial Statement Submission.

Profitability is the company's ability to earn profits. One indicator of a company's success in financial terms can be seen from its profitability. High profitability and low losses are considered good news for a company (Ha et al., 2018). Companies that have good news will usually publish financial statements early. Afify (2009) shows that companies will not want to disclose not good information to the public so they postpone the publication of financial statements. Return on assets (ROA) is one of the ratios to measure profitability. ROA indicates the efficiency of using assets to earn a profit. Zandi and Abdullah (2019) examines company performance using a return on assets and return on equity to the timeliness. The results obtained return on assets and return on equity have a significant relationship with the timeliness of financial reporting. However, that finding was different from Rahmawati (2018). Rahmawati (2018) found, profitability is a variable that does not affect the timeliness of financial reporting. Research on return on assets is also carried out by Alkhatib and Marji (2012), which 
found that profitability ratios are positively correlated with audit timeliness in service companies. In contrast, in ind ustrial companies, profitability ratios have a negative effect on audit timeliness. According to Ahmed and Hossain (2010), profitability has a significant impact on the timeliness of audit reports. In signal theory, high corporate profits encourage management to announce the information as soon as possible. High profits provide a signal to investors to support the current management position. When the company's profit is high, the manager immediately submits financial reports to investors in order to obtain performance recognition. The results of research by Danaatmaja and Suzan (2016), Dewi, Winanto \& Putra (2016), Astuti \& Teguh (2016), show that Return on Assets has a significant influence and has a positive direction on the timeliness of financial statement submission. This proves that companies that have high profits give a good impression to investors.

$\mathrm{H}_{2}$ : Return on Assets has a Positive Affect on Timeliness of Financial Statement Submission.

The company's size can be expressed in terms of the number of employees, total assets, the value of sales, and market capitalization. This study uses total assets as company size. Company size is one of the most widely used variables that determine the timeliness of audits. Research findings of Alkhatib and Marji (2012) show that in service sector companies, inability to meet audit deadlines is inversely associated to company size. People perceive that large companies are of greater concern than small companies. To maintain a good reputation in the community, large companies tend to be more timely in submitting financial reports. The research's results of Ha et al. (2018), Kusumaw ardani \& Priyadi (2018), and Hastutik (2015), explains that company size affects the timeliness of submitting financial statements. The larger the size of the company, the more resources it has. More sophisticated accounting and information systems staff and have a strong internal control system. This condition will accelerate the completion of financial statements. By contrast, for industrial sector firms, business size is adversely connected with audit timeliness. Hamidi \& Rasouli (2016) found no meaningful relationship between company size and timely financial reports. The size of the company did not influence audit time and timeliness. The company's size significantly reduces time in preparing the audit (Alkhatib \& Marji, 2012).

Several results have been conducted by several researchers, but the results show different findings. Differences in research results encourage research with various types of companies, time, and analytical tools.

$\mathrm{H}_{3}$ : Company Size has a Positive Affect on Timeliness of Financial Statement Submission.

This research is conducted on mining companies because securities analysts predict that in the next five years demand for mining, especially coal, will still be maintained. The mining sector is one of the contributors to non-tax state revenue.

\section{RESEARCH METHODS}

This research was a quantitative study involving the use of secondary data. Secondary data on the current ratio, return on assets, and firm size were derived from financial statements of mining companies that were publicly traded on the Indonesian stock exchange. Another piece of data examined in this study was the 
timeliness with which financial statements were submitted. The data was gathered via the Indonesia Stock Exchange's website, which can be accessed at the URL address www.idx.co.id. This analysis included all mining businesses that were listed on the Indonesian Stock Exchange (IDX) between 2016 and 2018. Purposive sampling was utilized as the sample technique. The criteria used were: 1) The mining companies listed on the Indonesia Stock Exchange for the period 2016 to 2018 ; 2) the company was not delisted during the period 2016 to 2018; 3) the companies had data on current ratio, return on assets, and company size, and the date of submission of annual financial statements from 2016 to 2018.

Each research variable is measured by the following formula.

$$
\begin{array}{ll}
\text { Current ratio } & =\frac{\text { Current ratio }}{\text { Current liabilities }} \\
\text { Return on Assets } & =\frac{\text { Net income }}{\text { Total assets }} \\
\text { Company size } & =\text { Ln (total assets) }
\end{array}
$$

The variable of the timeliness of the submission of financial statements is measured using a dummy variable. Companies that do not submit their financial statements on time are given a score of zero and companies that are on time are given a score of 1 . This research data was panel data. The analytical tool suitable for panel data types was eviews9. To analyze this research, a Logistic Regression Model was used. This model was ideal because there were binary variables. Binary variables are variables that use the values of 0 and 1 . Logit model estimation was done by the Likelihood Method (LM), which was looking for regression coefficients so that the probability of occurrence of the dependent variable could be as maximum as possible. Evaluation of the significance of the independent variable on the dependent variable used the statistical value $Z$. To test the feasibility of the model, whether all explanatory variables together affected the dependent variable used LR statistical tests.

\section{RESULTS AND DISCUSSION}

The results of statistical analysis of the data in this study were analyzed with descriptive statistics as shown in Table 1 . The data includes research variables, namely the timeliness of submitting financial statements, $\mathrm{CR}$, ROA, and company size.

Table 1. Descriptive Statistical Analysis Results

\begin{tabular}{lcccc}
\hline & Timeliness & CR & ROA & Size \\
\hline Mean & 0.681 & 190.520 & 4.275 & 12.815 \\
Maximum & 1.00 & 749.77 & 22.18 & 15.89 \\
Minimum & 0.00 & 21.37 & -12.24 & 8.79 \\
Std. Deviation & 0.469 & 151.421 & 6.276 & 1.170 \\
$\mathrm{~N}$ & 69 & 69 & 69 & 69 \\
\hline
\end{tabular}

Source: Research Data, 2021

The variable current ratio (CR) has an average value (mean) of 190.5209. CR shows how much a company's short-term liabilities are paid with current assets. The mean is 190.5209 interpreted that every 100 short-term liabilities will be paid with 190.5209 current assets. So it can be concluded that, on average, the company is in a liquid condition. The minimum CR is 21.37 occupied by PT Trada 
Alam Minera (TRAM) in 2016, while the maximum value is 749.77 occupied by Vale Indonesia (INCO) in 2018. The standard deviation is 151.42112. The standard deviation value is high enough so that the data spreads away from the mean.

The mean, maximum, minimum, and standard deviation values for the ROA variable were 4.2757, 22.18, -12.24, and 6.27689. Cita Mineral Investindo Tbk. (CITA) is the company with the highest ROA value. Meanwhile, PT Trada Alam Minera Tbk. (TRAM) in 2016 had the lowest ROA. The standard deviation of the ROA is above the mean, so it is indicated that the data are spread far apart. ROA shows the company's ability to generate profits by utilizing its assets. The mean ROA of 4.2757 shows that every 100 assets generate a profit of 4.2757 . The average ROA is low due to many companies getting losses.

The maximum and minimum values of the firm size variable (size) are not too different. Likewise, the standard deviation is small, and lower than the mean. That is, the spread of the data is quite close. This condition occurs because the size of the company has been made natural logarithm so that the data becomes smoother. The mean, maximum, minimum, and standard deviation are 12.8152, $15.89,8.79$, and 1.17066. The company with the lowestcompany size is Citatah Tbk. (CTTH) in 2016 and the highest is PT Petrosea Tbk. (PTRO) in 2018.

The maximum and minimum variable values for timeliness have no meaning because the data for timeliness is nominal data ( 1 or 0$)$. The mean is 0.6812 , which means that there are more companies that submit financial reports on time than those that do not. Analysis of the data in this study used the Eviews 9 program because the data used are panel data. The population in this study is 47 companies. The determination of the sample is carried out through the following stages (Table 2).

Tabel 2. Determination of Sample

\begin{tabular}{lr}
\hline Criteria of sample & Total \\
\hline $\begin{array}{l}\text { Number of mining companies listed on the BEI that were not delisted during } \\
\text { the 2016-2018 period }\end{array}$ & 47 \\
Number of companies that were not delisted during the 2016-2018 period & 43 \\
Number of mining companies listed on the Indonesia Stock Exchange for the & 23 \\
period 2016-2018 that present the data used in this research & \\
Number of sample & 3 \\
Period of research observation (years) & 69 \\
\hline
\end{tabular}

Source: ResearchData, 2021

The data in this study are tested in stages, starting from evaluating the whole model, the Hosmer \& Lemeshow test, the model accuracy test, and the hypothesis test. Evaluation of the model as a whole is seen from the LR statistical value and McFadden R-squared. The results of data analysis to determine the effect of the current ratio, return on assets, company size on the timeliness of financial statements on mining companies listed on the Indonesia Stock Exchange can be seen in Table 1 . 
Table 3. Evaluating Whole Model

\begin{tabular}{cl}
\hline \multicolumn{1}{c}{ Overall Model Evaluation } \\
\hline McFadden R-squared & 0.194 \\
LR statistic & 16.797 \\
Prob(LR statistic) & 0.000 \\
Goodness-of-fit & \\
Hosmer \& Lemeshow & 15.478 \\
ProbH-L statistic (8) & 0.0505 \\
\hline
\end{tabular}

Source: ResearchData, 2021

Based on Table 3, the LR statistical value is 0.000 . This value is less than 0.01 , so the model is feasible to use. It means that all variables such as current ratio, return on assets, and company size simultaneously can affect the timeliness of financial statement submission. Table 3 also shows the McFadden R-squared (R2McF) value is 0.194 . It indicates that $19.44 \%$ of the accuracy of the submission of financial statements is explained by the variables of the current ratio, return on assets, and company size. While as much as $80.56 \%$ is explained by other variables.

Hosmer and Lemeshow test results obtain a significant probability of 0.0505 . This value is higher than 0.05 . This result means that the model can predict observational data with its observation model. There is no real difference between the expected classification and the observed classification.

Table 4. Prediction Accuracy Test Results

\begin{tabular}{llll}
\hline \multirow{2}{*}{ Observation } & Prediction & \% True \\
\cline { 2 - 3 } & $1, \mathrm{P}>0.50$ & $0, \mathrm{P}<=0.50$ & 91.49 \\
1, timely & 43 & 4 & 45.45 \\
0, not timely & 12 & 10 & 76.81 \\
\% Correct(overall) & & & \\
\hline
\end{tabular}

Source: Research Data, 2021

According to Table 4, the accuracy of the model in predicting the timeliness of financial statement submission is $91.49 \%$, while predicting the timeliness of the submission of financial statements is $45.45 \%$. Overall, the logit model estimated in this study showed an accuracy of $76.81 \%$. Hypothesis test results partially the effect of current ratio, return on assets, and company size on the timeliness of financial submission statements can be seen in Table 5 .

Table 5. Logistic Regression Analysis Results

\begin{tabular}{lcccc}
\hline Variable & $\beta$ & SE $\beta$ & Statistic $z$ & Prob. \\
\hline A constant & 1.532 & 3.442 & 0.445 & 0.656 \\
CR & 0.010 & 0.004 & 2.573 & 0.010 \\
ROA & 0.098 & 0.054 & 1.803 & 0.071 \\
LN_TA & -0.218 & 0.266 & 0.820 & 0.412 \\
\hline
\end{tabular}

Source: Research Data, 2021

Based on Table 5, the logit regression model is obtained as follows.

$\bar{Z}_{\iota}=1.532217+0.010946 \times C R_{i}+0.098046 \times R O A_{i}-0.218330 \times L N_{-} T A_{i}$

The test results show that the coefficient of the current ratio is positive, with a probability value of 0.010 . Using a significance level of $5 \%$, it is concluded that the current ratio has a significant effect on the timeliness of financial statement submission. This is indicated by the probability value (0.010). The amount of the current ratio determines the timeliness of financial statement submission. The higher the company's current ratio, the greater the possibility that the company 
submits financial statements on time a timely manner. Conversely, the smaller the current ratio, the less likely the company to provide financial statements on time. A high current ratio indicates the company's ability to pay off its debt is getting bigger. Thus the company will quickly submit its financial statements to the public because the company has no problems in short-term debt. This condition is good news for the company. Good news encourages companies to submit financial statements on time to attract investors. The results of this study support Lukason and Camacho-Miñano (2019), which state that companies with low liquidity tend to delay delivering commercial finance. Other research proved that the current ratio significantly affects the timeliness of submitting financial statements (Hastutik, 2015), (Dewi et al., 2021) and (Fili \& Wahyuningsih, 2020). A high current ratio indicates the company's ability to pay off short-term obligations faster. This condition encourages companies to submit financial reports as soon as possible. Creditors become interested in providing loans to the company. Likewise, investors believe that they will get dividend payments on time.

A probability value of return on assets is 0.071 . This value is higher than the significance of the test (5\%). It means that the return on assets has no significant effect on the timeliness of financial statement submission. Companies with high profits do not guarantee that they will submit financial statements on time. Specifically, the mining companies that are sampled in this study consider that high profits will have an impact on the increased distribution of dividends and taxes. If the financial statements are submitted faster, then high dividends and taxes will be paid immediately. Therefore, with high profits, the company does not offer financial statements on time. Alkhatib \& Marji (2012), Rahmawati (2018), AlJuaidi \& Al-Afifi (2016), Raihani et al. (2019) found the same results that profitability did no effect on the timeliness of financial statements. Fili \& Wahyuningsih (2020); Indrayenti \& Ie (2016) found that there was no significant relationship between return on assets and the timeliness of financial statement submission. Return on assets does not affect the company in submitting financial statements. Go public companies have an obligation to submit financial reports in a timely manner if they do not want to be subject to fines for late submission of financial statements (Fili \& Wahyuningsih, 2020).

The coefficient of the company size variable is -0.218 and probability value is 0.412 . So it can be interpreted that the company size variable does not influence the significance of the timeliness of financial statement submission. Large or small companies do not guarantee to submit financial statements on time. Large companies usually have considerable assets. Provisions for recognizing assets are very complex; the results in the submission of financial statements cannot be done on time. Large companies are often inaccurate in reporting financial statements because large companies have broad business networks, larger product, and service volumes. More complex capital structures also caused the companies to postpone submitting their financial statement. Large companies often delay the announcement of financial statements because large companies have a wide business network, larger volume of products and services, the structure is more complicated than small firm (Durand, 2019). The study results support the findings of other researchers (Alkhatib \& Marji, 2012), (Asmara \& Situanti, 2018), (Gulec, 
2017), (Hamidi \& Rasouli, 2016), (Türel, 2010), (Savitri et al., 2019), (Raihani et al., 2019), (Indrayenti \& Ie, 2016).

\section{CONCLUSION}

The results of data analysis and discussion in this study conclude that the current ratio affects the timeliness of reporting financial statements. A high current ratio indicates the company's ability to pay its debts. This condition is good news that must be immediately conveyed to creditors. Return on assets does not have a significant positive effect on the timeliness of financial statement submission. Companies assume that high profits mean having to pay taxes and dividends. Therefore they are not interested in submitting financial reports on time. Company ize does not significantly impact the timeliness of the submission of financial statements to mining companies. Large companies have more complex assets and capital structures. They take a long time to make financial reports.

\section{REFERENCES}

Afify, H. A. E. (2009). Determinants of audit report lag. Journal of Applied Accounting Research, 10(1), 56-86. https:/ / doi.org/10.1108/09675420910963397

Ahmed, A. A. A., \& Hossain, S. (2010). Audit Report Lag: A Study of the Bangladeshi Listed Companies. ASA University Review, 4(2). https:/ / doi.org/10.2139/ssrn.3406733

Al-Juaidi, O., \& Al-Afifi, A. A. M. (2016). The Factors Affecting Timeliness of Corporate Financial Reporting: Empirical Evidence from the Palestinian and Amman Stock Exchange. International Journal of Management Sciences and Business Research, 5(10), 123-135.

Alkhatib, K., \& Marji, Q. (2012). Audit Reports Timeliness: Empirical Evidence from Jordan. Procedia - Social and Behavioral Sciences, 62, 1342-1349. https:/ / doi.org/10.1016/j.sbspro.2012.09.229

Asmara, R., \& Situanti, R. (2018). The Effect of Audit Tenure and Firm Size on Financial Reporting Delays. International Journal of Economics and Business Administration, 6(3), 115-126. https://doi.org/10.35808/ijeba/170

Astuti, W., dan Teguh, E., (2016). Pengaruh Profitabilitas, Umur Perusahaan dan Ukuran Perusahaan dan Ukuran Perusahaan terhadap Ketepatan waktu Penyampaian Laporan Keuangan Perusahaan (studi pada perusahaan manufaktur yang terdaftar di BEI tahun 2012-2016). Jurnal Kajian Bisnis, 26(2), 144-15.

Atiase, R., Bamber, L., \& Senyo, T. (1989). Timeliness of financial reporting, the firm size effect, and stock price reactions to annual earnings announcements*. Contemporary Accounting Research, 5(2), 526-552. https:/ / doi.org/https:// doi.org/10.1111/j.1911-3846.1989.tb00722.x

Bagnoli, M., Kross, W., \& Watts, S. G. (2002). The Information in Management's Expected Earnings Report Date: A Day Late, a Penny Short. Journal of Accounting Research, 40(5), 1275-1296. https:/ / doi.org/https:// doi.org/10.1111/1475-679X.t01-1-00054

Danaatmaja, A.R., dan Suzan, L., (2016). Pengaruh Rasio Keuangan Terhadap Ketepatan Waktu Penyampaian Laporan Keuangan (studi empiris pada 
perusahaan pertambangan yang terdaftar di BEI periode 2012-2016). EProceeding of Management, 5(1).

Dewi, D. K., Winanto, W., dan Putra, M., (2016). Pengaruh likuiditas, profitabilitas, leverage, ukuran perusahaan dan struktur kepemilikan terhadap ketepatan waktu pelaporan keuangan pada perusahaan manufaktur yang terdaftar di BEI tahun 2014-2016. Skripsi, Fakultas ekonomi Warmadewa

Dewi, N. P. Y., Novitasari, N.L. G., \& Dewi, N. L.P.S. (2021). Pengaruh profitabilitas, likuiditas, ukuran perusahaan, dan leverage terhadap ketepatan waktu penyampaian laporan keuangan. 3(2), 243-254.

Durand, G. (2019). The determinants of audit report lag: a meta-analysis. Managerial Auditing Journal, 34(1), 44-75. https:/ / doi.org/10.1108/MAJ-062017-1572

Fili, M., \& Wahyuningsih, D. (2020). Pengaruh return on assets, current ratio, dan deb to equity ratio terhadap ketepatan waktu penyampaian laporan keuangan. Widyakala Journal, 1(1), 135-146. https:/ / doi.org/10.36262/widyakala.v3i0.21

Graham, J. R., Harvey, C. R., \& Rajgopal, S. (2005). The economic implications of corporate financial reporting. Journal of Accounting and Economics, 40(1-3), 373. https:/ / doi.org/10.1016/j.jacceco.2005.01.002

Gulec, Ö. (2017). Timeliness of Corporate Reporting in Developing Econo mies: Evidence From Turkey. Journal of Accounting and Management Information Systems, 16, 219-239. https:// doi.org/10.24818/jamis.2017.03001

Ha, H. T. V., Hung, D. N., \& Phuong, N. T. T. (2018). The study of factors affecting the timeliness of financial reports: The experiments on listed companies in Vietnam. Asian Economic and Financial Review, 8(2), 294-307. https:/ / doi.org/10.18488/journal.aefr.2018.82.294.307

Hamidi, G, \& Rasouli, H. (2016). Evaluation of the Relationship between Accounting Variables and Timelines of Annual Reports of Accepted Companies in Tehran Stock Exchange. Mediterranean Journal of Social Sciences, 7(4), 117-123. https:/ /doi.org/10.5901/mjss.2016.v7n4s2p117

Hamidi, Ghasem, \& Rasouli, H. (2016). Evaluation of the Relationship between Accounting Variables and Timelines of Annual Reports of Accepted Companies in Tehran Stock Exchange. Mediterranean Journal of Social Sciences, 7(4), 117-123. https:/ /doi.org/10.5901/mjss.2016.v7n4s2p117

Hastutik, S. (2015). Pengaruh Profitabilitas, Likuiditas, Struktur Kepemilikan, Ukuran Perusahaan, dan Opini Audit terhadap Ketepatan Waktu Pelaporan Keuangan Perusahaan. 11, 101-106.

Indrayenti, \& Ie, C. (2016). Analisis faktor-faktor yang mempengaruhi ketepatan waktu penyampaian laporan keuangan pada perusahaan manufaktur. Jumal Akuntansi \& Keuangan, 7(1), 121-135.

Kasmir. (2019). Analisis Laporan Keuangan. Raja Grafindo Persada.

Kusumawardani, R., \& Priyadi, M. P. (2018). Pengaruh Ukuran Perusahaan, Umur Perusahaan, dan Leverage terhadap Ketepatan Waktu Pelaporan Keuangan dengan Profitabilitas sebagai Moderating. Jurnal Ilmu Dan Riset Akuntansi, 7(5), $1-17$. http://jurnalmahasiswa.stiesia.ac.id/index.php/jira/article/download/200 $/ 204$ 
Lukason, O., \& Camacho-Miñano, M.-M. (2019). Bankruptcy Risk, Its Financial Determinants and Reporting Delays: Do Managers Have Anything to Hide? In Risks (Vol. 7, Issue 3). https://doi.org/10.3390/ risks7030077

Rahmawati, E. (2018). Information content and determinants of timeliness financial reporting: Evidence from an emerging market. Academy of Accounting and Financial Studies Journal, 22(4), 1-15.

Raihani, A. S., Prasetyo, T. J., \& Dharma, F. (2019). Factors Affecting the Delay of Company Financial Statements. International Journal for Innovation Education and Research, 7(12), 246-255. https:/ /doi.org/10.31686/ijier.vol7.iss12.2044

Rakhman, F., \& Wijayana, S. (2019). Determinants of financial reporting quality in the public sector: Evidence from Indonesia. International Journal of Accounting, 54(3), 1-35. https://doi.org/10.1142/S1094406019500094

Savitri, E., -, A., \& Surya, R. A. S. (2019). Influencing Factors:The Timeliness of Financial Reporting Submissions. Business and Management Studies, 5(1), 43. https:/ / doi.org/10.11114/bms.v5i1.4144

Sengupta, P. (2004). Disclosure timing: Determinants of quarterly earnings release dates. Journal of Accounting and Public Policy, 23(6), 457-482. https:/ / doi.org/10.1016/j.jaccpubpol.2004.10.001

Soltani, B. (2002). Timeliness of corporate and audit reports: Some empirical evidence in the French context. The International Journal of Accounting, 37(2), 215-246. https:/ / doi.org/https:// doi.org/10.1016/S0020-7063(02)00152-8

Suadiye, G. (2019). Determinants of the timeliness of financial reporting: empirical evidence from turkey. Hacettepe University Journal of Economics and Administrative Sciences, 37(2), 365-386. https:/ / doi.org/10.17065/huniibf.399838

Türel, A. (2010). Timeliness of Financial Reporting in Emerging Capital Markets: Evidence from Turkey. European Financial and Accounting Journal, 5(3), 113133. https:/ / doi.org/10.18267/j.efaj.58

Umobong, A. (2015). Assessing the Impact of Liquidity and Profitability Ratios on Growth of Profits in Pharmaceutical Firms in Nigeria. European Journal of Accounting, Auditing, and Financial Resources, 3(10), 97-114.

Zandi, G., \& Abdullah, N. (2019). Financial statements timeliness: The case of Malaysian listed industrial product companies. Asian Academy of Management Journal, 24, 127-141. https:/ / doi.org/10.21315/aamj2019.24.s2.9 